\title{
Kunst og ansvarlighed
}

Denne artikel er det tidligst kendte arbejde fra Bachtins hånd. Den blev første gang trykt i tidsskriftet (en engangsudgivelse) Kunstens dag (Den' iskusstva) i Nevel, 13. september, 1919. Narvarende oversattelse er af teksten fra Éstetika slovesnogo tvoreestva, Moskva, 1979.

En helhed kaldes mekanisk hvis dens enkelte elementer kun er forenet i rum og tid ved hjælp af en ydre forbindelse og ikke gennemtrængt af en indre meningsmæssig enhed. Delene $i$ en sådan helhed ligger ved siden af hinanden og kommer i berøring med hinanden, men alligevel er de i sig selv fremmede over for hinanden.

Tre områder inden for den menneskelige kultur - videnskaben, kunsten og livet - finder kun sammen i det individ som kan forene dem i sig. Men denne forbindelse kan blive mekanisk, ydre. Desværre er det oftest også sådan. Kunstneren og mennesket er på naiv, oftest mekanisk vis, forenet i ét individ; mennesket fordyber sig midlertidigt i skaberværket for at komme væk fra »hverdagens problemer « og ind $\mathrm{i}$ en anden verden af »inspiration, liflige lyde og bøn« (Pusjkin: Digteren og pøblen (Poet i tolpa) (sidste vers)). Og med hvilket resultat? Kunsten bliver alt for kæphøj og selvsikker, alt for patetisk, for den skal jo ikke indestå for livet, som selvfølgelig ikke kan måle sig med sådan en kunst. »Hvad har vi at gøre der, « siger livet, »det dér er kunst, her har vi bare hverdagens prosa.«

Når et menneske er i kunsten, er det ikke i livet, og omvendt. Der er ikke mellem dem en enhed og gensidig indtrængen i individets indre kerne.

Hvad kan garantere den indre forbindelse af elementer hos individet? Kun en fælles ansvarlighed. For det som jeg oplever og forstår i kunsten, skal jeg indestå med mit liv, for at alt det oplevede og forståede ikke skal forblive uvirksomt i mit liv. Men ansvarlighed er også forbundet med skyld. Livet og kunsten skal ikke blot bære et gensidigt ansvar, men også skyldfølelse over for hinanden. Digteren skal huske, at hans poesi er skyld i livets banale prosa, og vi almindelige mennesker skal vide, at vores manglende fordringsfuldhed og seriøsitet i livets spørgsmål er skyld i kunstens goldhed. Individet skal være fuldstændig ansvarligt: alle dets momenter skal ikke bare passe ind i en tids- 
mæssig rækkefølge i dets liv, men de skal også gennemtrænge hinanden i en enhed af skyld og ansvarlighed.

Og man skal ikke bruge inspiration som undskyldning for at retfærdiggøre uansvarlighed. Inspiration som ignorerer livet og selv bliver ignoreret af livet, er ikke inspiration, men besættelse. Den sande, og ikke den selvbestaltede idé i alle de gamle spørgsmål om forholdet mellem kunsten og livet, om den rene kunst osv., dvs. disse spørgsmåls ægte patos, ligger ene og alene i at kunsten og livet hver især $\varnothing$ nsker at gøre deres egen opgave lettere, fralægge sig ansvaret, for det er nemmere at skabe uden at svare for livet, og det er nemmere at leve uden at tage hensyn til kunsten.

Kunsten og livet er ikke ét, men skal i mig blive forenet, skal forbindes i min ansvarlighed.

Oversattelse: Nina Møller Andersen. 